\title{
Income analysis of integrated farming system of dairy cow breeding farm, earthworms (Lumbricus rubellus), and citrus sinensis Valencia farm. Case study in Dau District, Malang Regency, East Java, Indonesia
}

\author{
Puji Akhiroh ${ }^{1}$, Hermanto ${ }^{1}$, Galih Purboningrum ${ }^{2}$, Mentari Bertha Septina Sase $^{2}$ and Rizki \\ Prafitri $^{1, *}$ \\ ${ }^{1}$ Faculty of Animal Science, University of Brawijaya, Jl. Veteran, Kota Malang, East Java, 65145, \\ Indonesia \\ ${ }^{2}$ Under Graduate, Faculty of Animal Science, University of Brawijaya, Jl. Veteran, Kota Malang, \\ East Java, 65145, Indonesia
}

\begin{abstract}
The integrated farming system between dairy cow breeding, earthworms (Lumbricus rubellus), and citrus (Citrus sinensis valencia) plantations provides regular income for farmers and sustainable farming. This research aims to analyze farmers' income based on the integrated farming system that has been done on these three commodities. This study utilized quantitative and qualitative methods to analyze data. Data were collected through questionnaires to 15 farmers who are members of Gading Kulon Farmer Group in Dau District, Malang Regency, East Java, Indonesia followed by in-depth interviews with key respondents. The study showed that dairy cow breeding provided annual income which contributed up to $58 \%$ of household income. Meanwhile, earthworm farming provides weekly income and twice a year income for citrus farming. Depending on the land area, Earthworms farming contributed up to $10 \%$ of household income, and citrus plantation was $33 \%$, depending on the land area owned by farmers. The average income of Dairy cow breeding was Rp. 163,308,000 per year; the Average Income of earthworms was Rp. 27,058,000 per year, and the average income of citrus plants was $92,480,000$ per year. However, integrated farming of these commodities does not work well in the community due to farmers' lack of land and capital. Moreover, most respondents indicated that they were interested only in citrus farming because it is easier compared to dairy cow breeding and earthworm farming. Good cooperation from various parties is needed to increase the importance of integrated farming with these three commodities for sustainable farming in Indonesia.
\end{abstract}

\footnotetext{
*Corresponding author: rizkiprafitri@yahoo.com
} 


\section{Introduction}

Dairy cattle are one of the leading livestock commodities in East Java Province, with a population of more than 280 thousand heads in 2019 [1]. Although the dairy cattle population in 2018 was much lower in quantity compared to 2017 , in general, the dairy cattle population in East Java reached 50 percent of the total dairy cattle population in Indonesia. Likewise, the production of fresh milk in East Java is the highest production in Indonesia when compared to other regions. In 2018, fresh milk production in East Java reached more than 500,000 tons or $55.9 \%$ of Indonesia's total fresh milk production. However, fresh cow's milk production growth in Indonesia only reached 2 per cent per year. This growth is far below the growth in domestic demand for cow's milk which reaches 5\% per year. Domestic raw milk needs (SSDN), which reached 3.8 million tons per year, can only be met by domestic production of around 20 percent, while the rest still has to be imported from various countries such as Australia, New Zealand, and the United States [2].

Integration of dairy cattle breeding businesses owned by farmers with other businesses, namely earthworms (Lumbricus Rubellus) and Valencian sweet orange plantations (Citrus sinensis Valencia) provide a solution for farmers toget regular income during the maintenance of dairy calves. Farming business integration will be carried out by utilizing cow dung from dairy cattle breeding as earthworms feed (Lumbricus Rubellus) kept around the cowshed. Farmers harvested Earthworms (Lumbricus Rubellus) every day and provided regular farmers' income. In addition, the use of organic fertilizers on citrus plants owned will also provide additional income for farmers every time they harvest. Dairy cattle breeding business integrated with the maintenance of earthworms (Lumbricus Rubellus) and Valencia sweet oranges (Citrus sinensis Valencia) will provide regular income in daily, weekly, monthly and annual income for farmers. Integrated dairy cattle breeding business with the maintenance of profitable earthworms (Lumbricus Rubellus) and Valencian oranges (Citrus sinensis Valencia) will increase the interest of dairy farmers to conduct dairy cattle breeding businesses and at the end affecting the number of dairy cows in Indonesia.

Integrated dairy cattle breeding business has been started by the Gading Mandiri farmer group, in Dau District, Malang Regency since 2019. Gading Mandiri livestock group started a side business of cultivation earthworms by considering economic and environmental aspects. One of the positive impacts of dairy cattle breeding is reducing environmental pollution, especially local drainage channels by cow dung waste. The most obvious impact is on the quality of cleanliness and environmental aspects. Earthworm cultivation is one of the efforts to overcome cow dung waste and increase the economic income of farmers. However, farmers have not been able to calculate the business analysis they have. Therefore, this study analyzes the economic benefit of the integrated business that farmers have carried out.

\section{Materials and methods}

This research was conducted on the Gading Mandiri Cattle group, Dau District. This research was conducted using survey research methods and quantitative approaches. Data Collection Methods are:

1. Primary Data

a. Observation

The observation method is used as a way to collect the necessary direct data, facts and information in the field. Data collection was also carried out by observing and observingdirectly observing the research object, conditions and matters relating to field observation research 
b. Interview

Interview is a method of collecting data by conducting questions and answers (direct interviews) to the Gading Mandiri livestock group, one of the research subjects. Interviews must be done systematically and based on research objectives. Interviews conducted with group members aimed to obtain more in-depth information about the dairy cattle breeding business integrated with earthworms (Lumbricus Rubellus) and how this business has an economic and social impact on farmer groups and the Gading Kulon community in general.

2. Secondary Data

The method of collecting secondary data obtained from the Gading Mandiri Cattle groupand conducting this literature study includes literature studies, statistical data and other information by comparing books, journals, articles that are useful for obtaining information related to theories and concepts related to feasibility research. integration of dairy cattle breeding.

Data collected

The stages of data analysis that will be carried out include:

1. Capital Analysis

Capital or capital is raw materials or funds combined with production factors in land, tools, and labor to produce a new item.

2. Total Cost

$$
\mathbf{T C}=\mathbf{T F C}+\mathbf{T V C}
$$

- $\quad \mathrm{TC}=$ Total Cost

- $\quad$ TFC $=$ Total Fixed Cost

- $\quad$ TVC $=$ Total Variabel Cost

3. Revenue

Revenue in this study will be calculated based on the total production generated bythe sale of dairy cattle and earthworms multiplied by the selling price:

$$
\mathbf{R}=\mathbf{P} \times \mathbf{Q}
$$

Description:

- $\quad \mathrm{R}=$ Revenue

- $\quad \mathrm{P}=$ Price

- $\quad$ Q $=$ Quantity

If : TR $>$ TR : then profit will be obtained

$\mathrm{TR}=\mathrm{TC}:$ break even point or Break Even Point

$\mathrm{TR}<\mathrm{TC}$ : will result in loss

4. Break Even Point (BEP)

Break event point or BEP is the point where production costs equal revenue. BEP will be calculated using the formula:

$$
B E P(\text { price })=\frac{\text { Total Cost }(R p)}{\text { Quantity Production }(R p)}
$$


5. Profit

Calculation of profit or profitability value can be calculated by using a formula.

$$
\pi=\mathrm{TR}-\mathrm{TC}
$$

Description:

- $\quad \pi=$ Profit on milk storage unit (Rp/year)

- $\quad \mathrm{TR}=$ Total Revenue or total revenue at the milk storage unit (Rp/year)

- $\quad \mathrm{TC}=$ Total Cost or total cost of the milk storage unit (Rp/year)

6. Profitability Analysis

Profitability is a reflection of the company's capital ability to earn profits or profits. Profitability is a reflection of the efficiency of a company in using its working capital. Profitability can be calculated by the formula:

Description:

- $\quad \mathrm{R}=$ Profitability

- $\quad \mathrm{L}=$ Profit

- $\quad \mathrm{M}=$ Foreign capital + own capital

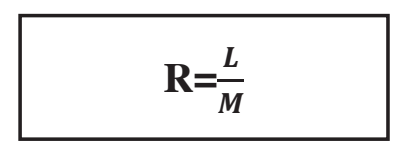

\section{Results and discussion}

\section{Livestock Population}

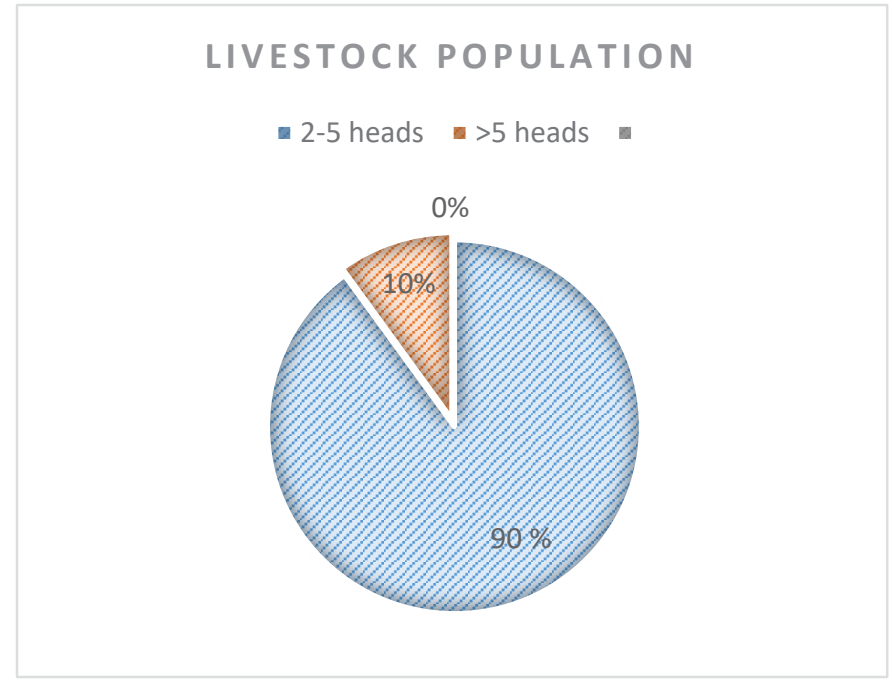

Fig. 1. Persentation livestock population

In the picture shows the experience of raising the 15 respondents who were interviewed divided into 2 groups. Respondents with a population of 2-5 cattle as much as $90 \% 5$ and for a livestock population $>5$ heads as much as $10 \%$. In the picture shows the experience of raising the 15 respondents who were interviewed divided into 2 groups. Respondents with a population of $2-5$ cattle as much as $90 \% 5$ and for a livestock population $>5$ heads as much as $10 \%$. This is in accordance with the opinion of Widayati et al. [3] which states that the number of cows has a positive influence on experience. 


\section{Type and number of livestock ownership}

The composition of the types of livestock kept by farmers in the Gading Mandiri livestock group, Dau District is very diverse, consisting of female dairy cows, lactating female cattle and some breeders who raise beef cattle. The number of livestock also greatly affects the income of livestock business.

Table 1. Number of Livestock Ownership in the Gading Mandiri Cattle Group

\begin{tabular}{|c|c|c|c|}
\hline No. & Type of Livestock & $\begin{array}{c}\text { Amount } \\
\text { Cattle (Heads) }\end{array}$ & $\begin{array}{c}\text { Amount } \\
\text { Respondent (Person) }\end{array}$ \\
\hline 1. & Integrated Dairy Cattle Breeding (Large Scale) & $18-20$ & 1 \\
\hline 2. & Lactation Dairy Business (Small Scale) & $3-4$ & 4 \\
\hline 3. & Dairy Cattle Business (Large Scale) & $18-20$ & 2 \\
\hline 4. & Beef Cattle Breeding (Small Scale & $3-4$ & 3 \\
\hline
\end{tabular}

Source: Harmoko et al. [4]

Based on the data in table 1 shows that the cattle breeding business owned by respondents from the Gading Mandiri livestock group is very diverse, ranging from small to large scale. In table 1 there is 1 farmer respondent who has an integrated large-scale dairy cattle breeding business. In addition, there are 4 farmer respondents have a small-scale lactation dairy cattle business of only 3-4 cows. For breeders who have a large-scale lactation dairy cattle business of up to 18 cows, only 2 people. This is according to Novarista et al. [5] that the difference in the number of cows kept is divided into three levels, namely 3 which illustrates that raising livestock is still a small business and is a side business, while if the number of cows is 4-10 it illustrates that the farmer's business is still not on an economic scale even though it may have become the main business, $>10$ headsillustrates that the farmer's business is already on an economic scale.

\section{Business Capital}

Business capital is operational cost capital used to facilitate running a business that runs out in one production process. The capital used in livestock groups comes from self-financing, cooperative loans or bank loans originating from the KUR (People's Business Credit) program. Asperinche et al. [6] stated that initial investment capital is the capital issued for a dairy cattle business, such as costs in purchasing livestock, cage costs, and equipment costs.. The production costs incurred by the dairy cattle breeding business owner in the Gading Mandiri Cooperative, Gading Kulon Village, Dau sub-district consist of 2 types, namely fixed costs and variable costs.

Table 2. Fixed costs in Dairy Cattle Breeding Business and Lactation Cattle Business

\begin{tabular}{|c|c|c|c|c|}
\hline No & Fixed Cost & Quantity & Unit price (IDR) & Total (IDR) \\
\hline 1. & Shrinkage of Cages and Warehouses & 1 & 250.000 & 250.000 \\
\hline 2. & property tax & 1 & 214.500 & 214.500 \\
\hline 3. & Equipment Depreciation & 1 & 41.500 & 41.500 \\
\hline \multicolumn{2}{|c|}{ Total Fixed Cost } \\
\hline
\end{tabular}


Source: Harmoko et al. [4]

In table 2, the largest expenditure is on the cost of depreciation of the cage and warehouse of Rp. 250,000. So that the total fixed costs in the dairy cattle breeding business and lactating cattle business are Rp. 506,000. Fixed costs between dairy and lactating cattle breeding businesses are considered the same, the difference is the variable cost. Expenditures on land and building taxes are taken on average from 10 farmer respondents. Variable costs in dairy farming and integrated with the cultivation of earthworms (Lumbricus rubellus) can be seen on table 3.

Table 3. Variable costs of production per period Data A

\begin{tabular}{|c|l|c|c|c|}
\hline No & \multicolumn{1}{|c|}{ Variable Cost } & Quantity & Unit price (IDR) & Total (IDR) \\
\hline 1. & 2 Months Dairy Cow Calf Breeding & 9 & $3.333 .333,33$ & 30.000 .000 \\
\hline 2. & Forage/period (kg) & 27.000 & 1.200 & 32.400 .000 \\
\hline 3. & Concentrate (kg) & 9.000 & 2.400 & 21.600 .000 \\
\hline 4. & Wormectin & 9 & 10.000 & 90.000 \\
\hline 5. & Vitamin B-Plex & 9 & 20.000 & 180.000 \\
\hline 6. & IB & 9 & 25.000 & 225.000 \\
\hline 7. & Sales Vehicle Rental & 16 & 35.000 & 400.000 \\
\hline 8. & Household and Enclosure Electric & 1 & 25.000 & 25.000 \\
\hline 9. & Household and Cage Water & 5 & 50.000 & 250.000 \\
\hline 10. & $\begin{array}{l}\text { Earthworm Seeds (Lumbricus } \\
\text { rubellus) }\end{array}$ & & & 85.730 .000 \\
\hline & Total Variable Cost & & & \\
\hline
\end{tabular}

Source: Harmoko et al. [4]

The data in table 3 shows the total variable costs of farmers. Variable costs are costs that will change every period. Variable costs include the cost of dairy cattle in the form of a 2month calf, forage feed and concentrates, medicines, vitamins, vaccines, AI, electricity, water, rental of sales vehicles and worm seeds. Based on table 3, the largest expense of variable costs is the cost of feed in the form of forage with the type of dry tumpi obtained from the cooperative at a price of Rp. 1,200,-/ kg and concentrate costs range from Rp. 2,400, - up to Rp. 2,600,- . kg and the cost of dairy cattle for 2 months is Rp. 3,333,333 per head or ordinary breeders make a purchase of IDR 10,000,000 for 3 calves aged 2 months. Data A is a type of calf that is 2 months old with a maintenance period of 1 period for 16 months. Data $\mathrm{B}$ is a type of calf with a maintenance period of 10 months in 1 period of 6 months. The earthworm cultivation business in table 3 does not use feed costs, because the earthworm feed comes from the use of dairy cow dung. Variable costs or variable costs are influenced by the livestock population, the more population you have, the greater the variable costs. 
Table 4. Variable costs of production per period Data B

\begin{tabular}{|c|c|c|c|c|}
\hline No & Variable Cost & Quantity & Unit price (IDR) & Total (IDR) \\
\hline 1. & $\begin{array}{l}2 \text { Months Dairy Cow Calf } \\
\text { Breeding }\end{array}$ & 9 & 9.000 .000 & 81.000 .000 \\
\hline 2. & Forage/period (kg) & 13.500 & 1.200 & 16.200 .000 \\
\hline 3. & Concentrate (kg) & 4.500 & 2.400 & 10.800 .000 \\
\hline 4. & Wormectin & 9 & 10.000 & 90.000 \\
\hline 5. & Vitamin B-Plex & 9 & 20.000 & 180.000 \\
\hline 6. & IB & 9 & 25.000 & 225.000 \\
\hline 7. & Sales Vehicle Rental & 2 & 200.000 & 400.000 \\
\hline 8. & $\begin{array}{l}\text { Household and Enclosure } \\
\text { Electric }\end{array}$ & 1 & 35.000 & 560.000 \\
\hline 9. & Household and Cage Water & 1 & 25.000 & 25.000 \\
\hline 10. & $\begin{array}{l}\text { Earthworm Seeds (Lumbricus } \\
\text { rubellus) }\end{array}$ & 5 & 50.000 & 250.000 \\
\hline & Total Variable Cost & & & $109,380,000$ \\
\hline
\end{tabular}

Source: Harmoko et al. [4]

Table 4 is a variable cost in Data B. The cost of seeds in data A and data B is very different due to differences in the age of dairy cows. Data A uses dairy cows aged 2 months at a price of Rp. 3,333,333 for Data B uses dairy cows aged 10 months at a price of Rp. 9,000,000,-The pattern of rearing for breeders who do dairy cattle breeding on a large scale, namely 18 cows, breeders have two different types of dairy cows, this also affects the cost of animal feed. The longer the maintenance of livestock, the greater the cost of feed and production costs. High feed costs are caused by the purchase of forage and concentrates. Farmers are still buying forage, because there is not enough forage in the fields. The type of forage given is corn tumpi. Breeders prefer corn tumpi because of the higher dry matter content than fresh forage. For the most part concentrate costs are subsidized by local cooperatives.

Data A shows that the total variable cost reaches Rp.85,730,000,- this is lower than Data $\mathrm{B}$, which has a total fixed cost of Rp. 109.380.000,-. This is because the cost of dairy calves is very high which reaches Rp. 9,000,000 per head. The cost of feed in Data A is higher, because the maintenance on Data A takes longer, so it requires a fairly high cost. This is done by farmers so that dairy cows that are kept at the age of 10 months can be harvested first at the age of 18 months. The results from the harvest can be used to finance the first loan of a cooperative or bank, and can be used for daily living.

The lactation cattle business in table 5. also shows the amount of costs required to purchase pregnant heifers. One pregnant heifer or lactating cow that will produce milk has a price of Rp. 17,000,000, - This is very different from a dairy cattle breeding business which buys calves aged 2 months at a price of Rp. 3,333,333, - and female dairy cows aged 10 month at a price of Rp. 9,000,000, - per head. The need for water in the maintenance of lactating cows is more, this is because the management process requires a lot of water to maintain the sanitation of the cage and dairy products. The following table 5 is a variable cost in large-scale lactation cattle business production. 
Table 5. Variable Costs of Large-Scale Lactation Cattle Production

\begin{tabular}{|c|l|c|c|c|}
\hline No & \multicolumn{1}{|c|}{ Variable Cost } & Quantity & Unit price (IDR) & Total (IDR) \\
\hline 1. & Pregnant heifer & 18 & 17.000 .000 & 306.000 .000 \\
\hline 2. & Forage/period (kg) & 77.760 & 1.200 & 93.312 .000 \\
\hline 3. & Concentrate/ period (kg) & 19.440 & 2.400 & 46.656 .000 \\
\hline 4. & Wormectin & 18 & 10.000 & 180.000 \\
\hline 5. & Vitamin B-Plex & 18 & 20.000 & 360.000 \\
\hline 6. & IB & 18 & 25.000 & 450.000 \\
\hline 7. & Milk Sales Transportation & 18 & 80.000 & 1.440 .000 \\
\hline 8. & $\begin{array}{l}\text { Household Electricity and Water } \\
\text { with Cage }\end{array}$ & 18 & 75.000 & 1.350 .000 \\
\hline 9. & Labor Wage (Month) & 18 & 600.000 & 10.800 .000 \\
\hline & Total Variable Cost & & 472.548 .000 \\
\hline
\end{tabular}

Source: Harmoko et al. [4]

Table 5 represents the variable costs of large-scale lactation cattle production with the maintenance of 18 cows. The biggest variable production costs in this business are pregnant heifers at a price of Rp. 17,000,000 per head. In addition, the other biggest cost is forage feed at a cost of IDR 93,312,000 per period or for 18 months. The cost of concentrate is also quite calculated because it takes a large amount of Rp. 46,656,000, -.

Table 6. Variable Costs of Small-Scale Lactation Cattle Production

\begin{tabular}{|c|l|c|c|c|}
\hline No & \multicolumn{1}{|c|}{ Variable Cost } & Quantity & Unit price (IDR) & Total (IDR) \\
\hline 1. & Pregnant heifer & 4 & 17.000 .000 & 68.000 .000 \\
\hline 2. & Forage/period (kg) & 17.280 & 1.200 & 20.736 .000 \\
\hline 3. & Concentrate/ period (kg) & 4.320 & 2.400 & 10.368 .000 \\
\hline 4. & Wormectin & 4 & 10.000 & 40.000 \\
\hline 5. & Vitamin B-Plex & 4 & 20.000 & 80.000 \\
\hline 6. & IB & 4 & 25.000 & 100.000 \\
\hline 7. & Milk Sales Transportation & 1 & 75.000 & 1.350 .000 \\
\hline 8. & $\begin{array}{l}\text { Household Electricity and Water with } \\
\text { Cage }\end{array}$ & & 100.994 .000 & \\
\hline & Total Variable Cost & & \multicolumn{3}{|c|}{} \\
\hline
\end{tabular}

Source: Harmoko et al. [4] 
Based on table 6. Regarding the variable costs of small-scale lactation cattle production, which only raises $3-4$ cows. Although the scale of this business is relatively small, the cost of forage feed in one period or 18 months is Rp. 20,736,000, - for concentrate feed costs, it costs Rp. 10,368,000, -. The difference in the variable costs of small and large scale lactation cattle production lies in the burden of labor costs. Lactation cattle business with a small scale, or having 3-4 livestock does not require hired labor for a lactation cattle business. Breeders in this case devote some of their time to developing cattle. The remaining labor time is allocated to other people's sideline farming businesses, so that farmers still get additional income.

Table 7. Initial Capital for Orange Business

\begin{tabular}{|c|c|c|}
\hline No & Land Area $\left(\mathbf{m}^{2}\right)$ & Initial Capital (IDR) \\
\hline 1. & 7.000 & 550.000 \\
\hline 2. & 7.500 & 500.000 \\
\hline 3. & 8.000 & 600.000 \\
\hline 4. & 10.000 & 600.000 \\
\hline 5. & 7.000 & 500.000 \\
\hline 6. & 10.000 & 600.000 \\
\hline 7. & 8.000 & 500.000 \\
\hline 8. & 7.000 & 500.000 \\
\hline 9. & 8.000 & 600.000 \\
\hline 10. & 7.000 & 550.000 \\
\hline 11. & 20.000 & 500.000 \\
\hline 12. & 8.000 & 600.000 \\
\hline 13. & 5.000 & 10.000 .000 \\
\hline 14. & 5.000 & 10.000 .000 \\
\hline 15. & 10.000 & 10.000 .000 \\
\hline
\end{tabular}

Based on table 7 regarding the business capital of oranges, it shows that the smallest capital spent to manage the citrus business by the respondents is Rp. 500,000 and the largest capital issued by the respondents is Rp. 10,000,000. In addition, respondents also use the smallest land 5,000 $\mathrm{m} 2$ and for the largest land 20,000 $\mathrm{m} 2$. There is limited land owned by respondents to be able to produce oranges on a large scale and included with the capital owned. However, a managed citrus business can provide more benefits even though there are limited land areas. 


\section{1 Production Cost (Total Cost)}

The calculation of production costs is the sum of the addition of fixed costs and variable costs. The determination of the cost of production is carried out by reducing production costs as low as possible and while maintaining the quality of the goods or products produced, this is in accordance with economic law to set production costs to a minimum to get maximum results, this causes the cost of goods produced by livestock to be higher. Lower than the previous one. The total cost of production (total cost) in the integrated dairy cattle breeding business in the Gading MandiriCattle Group, Gading Kulon Village, Dau District can be seen in table 7.

Table 8. Production Costs (Total Cost) of Integrated Earthworm Dairy Cattle Breeding Business

\begin{tabular}{|c|c|c|c|}
\hline No. & \multicolumn{1}{|c|}{ Cost Tyoe } & Data A (IDR) & Data B (IDR) \\
\hline 1 & Total Fixed Cost & 506,000 & 506,000 \\
\hline 2 & Total Variable Cost & 85.730 .000 & $109,380,000$ \\
\hline \multicolumn{2}{|c|}{ Quantity } & $86,236,000$ & $109,886,000$ \\
\hline \multicolumn{2}{|c|}{ Total Cost } & $196,122,000$ \\
\hline
\end{tabular}

Source: Harmoko et al. [4]

The data in Table 8 shows the total cost of production (total cost) in the breeder. The data shows that the production cost in Data A is Rp. 86,236,000,- for the production costs in Data B of Rp.196.122,000. The total production cost for an integrated dairy cattle breeding business with earthworms (Lumbricus rubellus) is Rp. 196,122,000 for a period of 18 months. One period will produce 1 harvest for dairy cattle breeding and 18 harvests for earthworms. The earthworm harvest period is done once a month, this is due to the fast breeding cycle. Several farmers who are members of the Gading Mandiri Livestock Group have activities to raise both dairy and beef cattle, so that many farmers have difficulty processing and utilizing cow dung waste properly. So that a dairy cattle breeding business is created that is integrated with the cultivation of earthworms (Lumbricus rubbelus). This is done so that farmers can utilize organic waste by cultivating earthworms (Lumbricis rubellus) so that they can create new business units based on science and technology so that they can develop entrepreneurial motivation among farmers.

Table 9. Business Production Costs (Total Cost) of Lactation Dairy Cattle Breeding

\begin{tabular}{|l|c|c|}
\hline \multirow{2}{*}{ Average/Period } & \multicolumn{2}{|c|}{ Breeder } \\
\cline { 2 - 3 } & 18 Lactation Dairy Cattle (IDR) & 3-4 Lactation Dairy Cows (IDR) \\
\hline Fixed Cost (Rp) & 506,000 & 506,000 \\
\hline Variable Costs (Rp) & 472.548 .000 & 100.994 .000 \\
\hline Total Cost (Rp) & 473.054 .000 & 101.500 .000 \\
\hline
\end{tabular}

Source: Processed Primary Data (2020) 
Based on the data in table 9, it can be seen that the total cost or the total production cost of large-scale lactating dairy cattle with 18 cows reached Rp.473,054,000. For production costs that must be incurred by small-scale farmers or with the maintenance of 3-4 heads reach Rp. 101,500,000. The price of beef cattle greatly determines the quality of dairy cows. Buying cattle seeds from the animal market is very risky, because breeders have the opportunity to get low quality or sick cows. Breeders only sell cattle seeds to the animal market if the quality of their cattle is not good, unless there is an urgent need to sell good quality cattle.

Table 10. Business Production Cost (Total Cost) of Orange Business

\begin{tabular}{|c|c|c|c|c|}
\hline \multirow{2}{*}{ No } & \multicolumn{3}{|c|}{ Total Tree Ownership } & \multirow{2}{*}{ Total Cost (IDR) } \\
\cline { 2 - 4 } & Siam Madu & Keprok & Baby & \\
\hline Quantity & 1740 & 1960 & 1400 & 236.000 .000 \\
\hline Average & 116 & 130,6667 & 93,33333 & $15.733 .333,33$ \\
\hline
\end{tabular}

Source: Harmoko et al. [4]

Based on table 10, it can be seen that the total number of ownership of Siam Honey trees is 1740 , tangerines are 1960 and baby oranges are 1400 so that the total cost to produce oranges is Rp. 236,000,000. Based on the opinion of Djumadil et al. [11] explained that the production received is not always the same because there are parts that have large revenues influenced by sufficient production costs and good planting and maintenance processes.

\section{2 Revenue (Total Revenue)}

Receipts can be divided into cash receipts and calculated receipts. Cash receipts are in the form of sales of livestock products or side businesses, while the income that is taken into account is the value of livestock products. Cash receipts for farmers who carry out integrated businesses come from the sale of by-products, namely earthworms, vermicompost and manure. For receipts that are taken into account in the form of sales of dairy cows. The average income received by farmers who have dairy cattle integrated with earthworms can be seen in Table 11.

Table 11. Acceptance of Earthworm Integrated Dairy Cattle Breeding

\begin{tabular}{|c|l|c|c|}
\hline No. & \multicolumn{1}{|c|}{ Revenue } & Total (IDR) & Contribution Percentage (\%) \\
\hline 1. & Dairy Cattle Seed Sales & 360.000 .000 & 90.85 \\
\hline 2. & $\begin{array}{l}\text { Sales of Earthworms and their } \\
\text { Components }\end{array}$ & 36.240 .000 & 9.14 \\
\hline & Total Sales & 396.240 .000 & 100 \\
\hline
\end{tabular}

Source: Harmoko et al. [4]

The data in table 11 shows the total income of farmers. Farmers' income is obtained from selling dairy cattle seeds as the main product and earthworms as a by-product. On average, breeders sell live dairy cattle at a price of around Rp. 20,000,000 with a live weight of 250 $\mathrm{kg}-300 \mathrm{~kg}$. The price of dairy cows depends on the quality of the dairy cows. In addition to selling dairy cattle as the main product, farmers also sell earthworms to cooperatives, catfish 
or fish owners with a fairly high selling price of Rp. 30.000,-/kg. Earthworms have derivative products in the form of worm droppings or what is known as vermicompost. Kascing has many benefits, namely it is used as a natural solid organic fertilizer which is fermented directly by earthworms.

The data listed in table 9 shows that the sales of dairy cattle breeds contribute $90.85 \%$ and earthworms contribute $9.14 \%$ of the revenue. The percentage contribution of earthworms and their components in table 10 is relatively small compared to the sale of dairy cattle breeds. Although the percentage of the contribution is quite small, it is very helpful in providing side income for farmers. If farmers only rely on income from dairy cattle breeding businesses, farmers only get income in the 6th and 18th months, as shown in table 12.

Table 12. Revenue Receipts From Dairy Cattle Breeding Business

\begin{tabular}{|c|c|c|c|}
\hline No & Month Income n-th & Quantity (Ekor) & Total Income (IDR) \\
\hline 1. & 6th Month Income & 9 & 180.000 .000 \\
\hline 2. & 18th Month Income & 9 & 180.000 .000 \\
\hline \multicolumn{2}{|c|}{ Total Revenue } & 360.000 .000 \\
\hline
\end{tabular}

Source: Harmoko et al. [4]

In Table 12 there are two periods of revenue receipts from dairy cattle breeding, this is because farmers keep dairy cows with different seed ages, namely dairy cows with 2 months and 10 months of seed purchase. Dairy cows are sold at the age of 18 months or at the age of 1.5 years at a price of Rp. 20,000,000 per head. Breeders prefer to buy dairy cattle from cooperatives, KUD or well-known breeders. The quality of dairy cows that come from cooperatives or better known breeders will be guaranteed. The price you get will be less expensive, than livestock in the animal market. Revenue from earthworm cultivation can be seen in table 13 below.

Table 13. Revenue from Earthworm Cultivation

\begin{tabular}{|c|c|c|c|}
\hline No & Month Income n-th & Quantity (Kg) & Total Income (IDR) \\
\hline 1. & 1stMonth Income & 29 & 870.000 \\
\hline 2. & 2ndMonth Income & 18 & 540.000 \\
\hline 3. & 3rdMonth Income & 123 & 3.690 .000 \\
\hline 4. & 4thMonth Income & 67 & 2.010 .000 \\
\hline 5. & 5th Month Income & 112 & 3.360 .000 \\
\hline 6. & 6th Month Income & 179,5 & 5.385 .000 \\
\hline 7. & 7th Month Income & 392,5 & 4.590 .000 \\
\hline 8. & 8th Month Income & 89 & 2.170 .000 \\
\hline 9. & 9th Month Income & 75 & 2.670 .000 \\
\hline 10. & 10thMonth Income & & 250.000 \\
\hline
\end{tabular}




\begin{tabular}{|c|c|c|c|}
\hline 11. & 11th Month Income & 61,5 & 1.845 .000 \\
\hline 12. & 12th Month Income & 88 & 2.640 .000 \\
\hline 13. & 13th Month Income & 76,5 & 2.295 .000 \\
\hline 14. & 14th Month Income & 124 & 3.720 .000 \\
\hline 15. & 15th Month Income & 84,5 & 2.535 .000 \\
\hline 16. & 16th Month Income & 48 & 1.440 .000 \\
\hline 17. & 17th Month Income & 168,5 & 5.055 .000 \\
\hline 18. & 18th Month Income & 152,5 & 4.575 .000 \\
\hline & Total Revenue & 1639,5 & 36.240 .000 \\
\hline
\end{tabular}

Source: Harmoko et al. [4]

The data in table 13 shows the total income of farmers who sell large and small scale lactation cows. Farmers' income is obtained from daily milk sales. The daily milk production obtained by farmers from two milkings in the morning and evening is 13 liters/day. Farmers get a price of Rp. 6,300, - for one liter of milk. The finished milk will be sold to PT. Nestle Indonesia. The amount of daily cow's milk production depends on several factors such as genetics, feed and rearing management. Sales receipts of large and small scale lactation cows to farmers are shown in table 14 below.

Table 14. Sales Revenue of Large and Small Scale Lactation Cattle

\begin{tabular}{|c|l|c|}
\hline No. & \multicolumn{1}{|c|}{ Revenue } & Total (IDR) \\
\hline 1. & Large-Scale Sales of Lactation Cattle (18 heads) & 796.068 .000 \\
\hline 2. & Small-Scale Lactation Cattle Sales (3-4 heads) & 176.904 .000 \\
\hline
\end{tabular}

Source: Harmoko et al. [4]

Table 15. Orange Business Revenue

\begin{tabular}{|c|c|c|c|c|}
\hline \multirow{2}{*}{ No } & \multicolumn{3}{|c|}{ Orange Revenue } & \multirow{2}{*}{$\begin{array}{c}\text { Revenue per year } \\
\text { (IDR) }\end{array}$} \\
\cline { 2 - 5 } & $\begin{array}{c}\text { Siam Madu } \\
(\mathbf{1 0 . 0 0 0 / k g )}\end{array}$ & $\begin{array}{c}\text { Keprok Batu 55 } \\
\mathbf{( 8 . 0 0 0 / k g )}\end{array}$ & Baby (8.000/kg) & \\
\hline Quantity & 278.400 .000 & 548.800 .000 & 560.000 .000 & 1.387 .200 .000 \\
\hline Average & 18.560 .000 & $36.586 .666,67$ & $37.333 .333,3$ & 92.480 .000 \\
\hline
\end{tabular}

Source: Harmoko et al. [4]

Based on table 15, it can be seen that the average orange revenue is Rp. 92,480,000 per year. In carrying out citrus farming, it is necessary to maximize income. This is in accordance with the opinion of Pramadinata, et al [10] which states that the acquisition of revenue value must be reduced by farming costs in order to obtain maximum income. 


\section{Income}

Revenue is the result obtained from the difference between receipts and costs or expenses. Income can be influenced by many factors, one of which is the scale of business, capital, labor efficiency and the level of production of farmers. This income is calculated by the farmer per period or for 18 months.

Table 16. Income from the Business of Integrated Earthworm Dairy Breeding

\begin{tabular}{|c|l|c|}
\hline No. & \multicolumn{1}{|c|}{ Income } & Total (IDR) \\
\hline 1. & Total Revenue & 396.240 .000 \\
\hline 2. & Total Production Cost (Total Cost) & $196,122,000$ \\
\hline & Total income & 200.118 .000 \\
\hline
\end{tabular}

Source: Harmoko et al. [4]

The data in table 16 shows that the net income of farmers for one period (18 months) is Rp. 200,118,000. Revenue is the result of revenue from the sale of dairy cattle which are integrated with earthworms. Revenues in table 10 have been deducted by production costs and land and building taxes. The amount of income of farmers depends on efficient production costs. This is in accordance with Ervina et al. [9] which states that the high and low income of dairy cattle is influenced by factors such as the number of ownership of lactating dairy cows, the selling price of livestock, the amount of milk production, labor wages, milk prices, and additional feed prices. The income of farmers who run dairy cattle breeding businesses and are integrated with earthworms is different from that of farmers who run lactating dairy cows. In table 17 below is the income of farmers who do lactation dairy cattle with two types, namely large and small scale.

Table 17. Business Income of Large and Small Scale Lactation Dairy Cattle

\begin{tabular}{|l|c|c|}
\hline \multirow{2}{*}{\multicolumn{1}{|c|}{ Income }} & \multicolumn{2}{c|}{ Total (IDR) } \\
\cline { 2 - 3 } & $\begin{array}{c}\text { Large Scale Lactation } \\
\text { Dairy Cows (18 Heads) }\end{array}$ & $\begin{array}{c}\text { Small Scale Lactation } \\
\text { Dairy Cows (4-5 Heads) }\end{array}$ \\
\hline Total Revenue & 796.068 .000 & 176.904 .000 \\
\hline Total Production Cost (Total Cost) & 472.548 .000 & 100.994 .000 \\
\hline Total income & 323.520 .000 & 75.910 .000 \\
\hline
\end{tabular}

Source: Harmoko et al. [4]

Based on table 17, the following is the income of farmers who come from lactating dairy cows. Large-scale lactating dairy farmers have a net income of IDR 323,520,000 per period, or $17,973,333$ per month with a total production cost of IDR 796,068,000. The net income earned for small-scale lactating dairy farmers is Rp. 75,910,000 per period or for 18 months. If calculated, the farmer will get Rp. 4,217,222 per month. Expenditure for production costs for small-scale farmers is Rp. 176,904,000. 
Table 18. Orange Business Income

\begin{tabular}{|l|c|}
\hline \multicolumn{1}{|c|}{ Income } & Total (IDR) \\
\hline Total Revenue & 1.387 .200 .000 \\
\hline Total Production Cost & 236.000 .000 \\
\hline Total Income & 1.364 .200 .000 \\
\hline
\end{tabular}

Based on table 18, the total revenue is Rp. $1,364,200,000$ of the total revenue which is deducted by the total production cost of all types of oranges that are managed.

\section{Business Contribution}

Calculating the business contribution means knowing how much influence the contribution of a dairy cattle business that is integrated with the cultivation of earthworms (Lumbricus rubellus) has on the income of the farmer's family. The following table 21 shows the contribution of dairy cattle breeding business to livestock income per period.

Table 19. Contribution of Earthworm Integrated Dairy Cattle Breeding Business

\begin{tabular}{|l|c|c|}
\hline \multicolumn{2}{|c|}{ Type of Business } & Contribution (\%) \\
\hline Dairy Cattle Breeding Business Income & 163.308 .000 & $88,29 \%$ \\
\hline Earthworm Cultivation Business Income & $27,058,000$ & $12,71 \%$ \\
\hline Total Farmer's Household Income & 184.966 .150 & $100 \%$ \\
\hline
\end{tabular}

Source: Harmoko et al. [4]

The contribution of dairy farming is $88.29 \%$ of the total household income of farmers per period. The contribution of earthworm business is $12.71 \%$ of household income. Farmer household income is generated by the main business of dairy cattle breeding with earthworm cultivation as another side income.

\section{Conclusion}

The research, which was conducted at the Gading Mandiri Cattle group, Dau District, became the integration of dairy cattle breeding businesses owned by farmers with other businesses, namely earthworms (Lumbricus Rubellus) and Valencian sweet orange plantations (Citrus sinensis Valencia) which is one way out so that farmers can earn income regular in the dairy calf rearing period. However,integrated farming of these commodities does not work well in the community due to farmers' lack of land and capital. Moreover, most respondents indicated that they were interested only in citrus farming because it is easier compare to dairy cow breeding and earthworm farming. Good cooperation from various parties is needed to increase the importance of integrated farming with these three commodities for sustainable farming in Indonesia. 


\section{References}

1. BPS-Statistics Indonesia, Populasi sapi perah menurut Provinsi 2009-2019, (2020).

2. Kementrian Pertanian, Buku outlook komoditas peternakan susu sapi (2019).

3. T.W. Widayati, I. Sumpe, Prosiding Seminar Teknologi Agribisnis Peternakan (STAP) Fakultas Peternakan Universitas Jenderal Soedirman, 7 (2020)

4. H. Harmoko, I. Ibrahim, N. Kusrianty, M. Marhayani, Cendekia Eksakta 5 (2021)

5. N. Novarista, M. Maiyontoni, R. A. Putra, H. D. Triani, Agrifo: Jurnal Agribisnis Universitas Malikussaleh, 5 (2020)

6. S. Asperinche, A. Widyasworo, AVES: Jurnal Ilmu Peternakan, 14 (2020)

7. G. A. R. Maria, S. T. Raharjo, Jurnal Kolaborasi Resolusi Konflik 2 (2020)

8. R. Fahlewi, R. C. Amri and A. M. Sari, Journal of Economic, Business and Accounting, 4 (2020)

9. D. Ervina, A. Setiadi, T. Ekowati, SOCA, 132 (2019)

10. B. Y. A. Pramadinata, N. Khoiriyah, L. R. Maula, Jurnal Sosial Ekonomi Pertanian dan Agribisnis, 9 (4) (2021)

11. N. Djumadil, Y. Syafie, Prosiding Seminar Nasional Agribisnis, 1 (1) (2020) 